\title{
Classy Whores: Intersections of Class, Gender, and Sex Work in the Ideologies of the Putafeminista Movement in Brazil
}

\section{Thaddeus Blanchette* \\ Ana Paula da Silva**}

\begin{abstract}
Brazil's sex workers' movement has long challenged hegemonic narratives about the sale of sex. In recent years, anti-prostitution sentiment has grown in Brazil, threatening sex workers' rights. Simultaneously, the death of activist Gabriela Leite has lead to a renewal of leadership and a reformulation of theoretical approaches in the movement. In this context, putafeminismo is becoming established as an intersectional approach to race, class, and gender rooted in local historical contexts. The present article, based on 12 years of ethnography in sex workers' movements, presents putafeminista understandings of sex, gender, race/color, and work. Inspired by Leite's recovery of whore/puta as a self-identifier for sex workers, and rooted in feminist anthropology and historiography, putafeministas seek to resituate the term as a broader/deeper category. Putafeministas recover puta as a term applied to women working outside the family, unprotected from sexual violence. Looking at Brazilian history, they situate the sale of sex as a practical inevitability for a raciallyidentified female working population, whose horizons of possibility were bounded by cheap labor, marriage and prostitution. Finally, putafeministas use puta as a bridge to working class experiences more generally, questioning pornophobic understandings of 'sexual slavery' in a historical context in which women were often actual chattel.
\end{abstract}

Keywords: Putafeminismo; Prostitution; Intersectionality; Brazil; Whores.

To the moralist prostitution does not consist so much in the fact that the woman sells her body, but rather that she sells it out of wedlock.

- Emma Goldman

\footnotetext{
* Federal University of Rio de Janeiro (UFRJ), Rio de Janeiro-RJ, Brazil; thaddeus.blanchette@gmail.com. ORCID iD 0000-0002-8828-3943.

** Fluminense Federal University (UFF), Niterói-RJ, Brazil; ana51@uol.com.br. ORCID iD 0000-0001-82188286.
} 


\section{Introduction}

The following paper is based upon 12 years of ethno- and historiographic research in Rio de Janeiro, Brazil, as well as extension work carried out with the Davida prostitutes' rights group and Brazil's anti-human-trafficking movements through the Federal University of Rio de Janeiro's Prostitution Policy Watch (Observatório da Prostituição). It discusses a set of topics related to the question of how to promote for women who sell $\operatorname{sex}^{1}$ a social justice agenda, defined, following Nancy Fraser (2009: 16), as 'dismantling institutionalized obstacles that prevent some people from participating on a par with others, as full partners in social interaction' and, in particular in this case, from participating as primary stakeholders in the construction of the policies that affect them. Here, we follow a growing intellectual and political trend in Brazil and Argentina - Putafeminismo, which postulates that fighting the social stigma of the whore is a necessary precondition for any social justice struggle involving sex workers.

We begin with an overview of how the current battles surrounding sex work are not being played out on a level playing field between equally matched sides. We explore the concept of pornophobia ${ }^{2}$ and its deeply set roots in the historical development of the concept of the whore. We look at some of the shortcomings of the theoretical lenses most commonly employed by feminism to explore prostitution. We describe how putafeminismo has developed in Brazil as an overarching alliance of sex workers, academics, feminists, and others who understand whore as a political term capable of creating bridges between sex workers and other working-class movements fighting against a neo-liberalism that threatens labour rights and democratic urbanism. In our concluding section, we look at what this movement structured around putafeminismo has done to date and outline what needs to happen, in the future, if we are to be successful at creating greater social justice for the women who sell sex in our country.

\section{On bullshit, whores, and feminism}

Moral philosopher Harry Frankfurt gave the world an analytical tool when he published his paper On Bullshit in 1986. Although the paper itself became a pop culture sensation, this does not diminish the utility of its key concept, especially when we turn to topics such as sex work/prostitution/whoring.

Frankfurt defined bullshit as a form of discourse separate from truth or lies. Truthful discourse describes reality as it appears to the person who attempts to tell the truth. Meanwhile, a liar still cares about the truth. They think they know what it is and want to hide it from others. Both lies and truthful discourse thus have a base connection to the truth, at least as it's perceived by liars and the truthful. Bullshit, however, has no necessary connection to truth, nor does it intentionally obfuscate, as a lie does. Bullshit is a form of rhetorical discourse that is solely concerned with persuading listeners. To this end, a good bullshitter promiscuously mixes facts and fantasies, truth and lies - all to convince an audience. 
Much of what is produced and popularized about the sale of sex is, frankly, bullshit. In part, this is because (as Jay Gould (1981) once pointed out with regards to race) when we don't have good data, politics tend to overwhelm science. There is a long list of popular bullshit statements about sex work which we could cite here. For lack of space, we will simply point interested readers to two articles by sex worker activist Maggie O'Neil (2012, $2014)^{3}$ which are an excellent starting point for debunking common prostitution myths such as the idea that the average age of entry into prostitution is 13 ; that $80 \%$ of prostitutes are coerced; and the constant confusion, in journalistic stories, of the categories of 'children at risk for sexual exploitation' and 'sexually exploited children.'

With the increasing popularity of the so-called 'Swedish model' (the criminalization of clients), bullshit has begun to dominate policy discussions surrounding prostitution. As Ann Jordan (2012) points out, there is no hard evidence that Sweden's policies have reduced prostitution. In fact, the Swedish government claims that trafficking in persons is still on the rise in the country, in spite of their laws. But one thing is quite clear: in criminalizing clients, Swedish authorities have decided to ignore the voices of sex-working women in favour of the voices of 'prostitution survivors,' radical feminists, and social workers. This has led to an operative definition of sex-working women as insane or otherwise unfit and to their progressive removal - on grounds of incompetence - from any further serious debate about prostitution laws in Sweden (Edlund and Jakobbson 2017). ${ }^{4}$

In another example of the phenomenon, Amnesty International's decision to support sex work decriminalization, taken after in-depth analysis of scientific studies regarding prostitution (Amnesty International 2016), was met by outcries that AI wished to legalize the exploitation of women. Again, those who want to criminalize sex work urged that Amnesty 'listen to survivors' ${ }^{5}$ instead of women actually engaged in sex work or the scientists studying it. Journalist Julie Bindel, in fact, claimed that if she had a gun and a single bullet, she would not shoot a pimp, but rather a sex work researcher (Agustin 2010). Anthropologist Laura Agustin (2010), commenting on Bindel's statement, remarked that the journalist seemed particularly incensed by ethnographers:

Not so many who research the sex industry are technically anthropologists, so maybe the criticism is against people who do ethnography. Which usually means not using formal interviews or quantitative surveys but spending a lot of time with the people being researched: living with them, or visiting them frequently over a long time, watching and listening, recording what you see, hear, smell, taste, feel. These days, ethnographers don't ordinarily claim their results to be final truths about large groups but rather suggestive small-scale pictures.

What does it mean to suggest any subject should not be researched? Is the implication that research harms some people, who are better served by those taking particular ideological stances towards them? 
It can be legitimately argued that both sides in today's prostitution wars spout bullshit, and engage in tactics such as 'de-platforming.' However, only one of the sides in this debate enjoys freedom from legal persecution and the general support of police and other State authorities. In fact, people who speak out for decriminalization are often slandered as 'the pimp lobby', leading one sex worker activist to remark, 'If we truly were supported by pimps or "the sex industry," they wouldn't call us that because they'd know we'd have the resources to sue' (Pye Jakobbson, interview by authors, July 2017).

In Brazil, accusations that sex workers and sex work researchers are part of some well-funded international conspiracy are even more ridiculous. Currently, almost none of the country's $30+$ sex worker associations can pay their bills, let alone effectively lobby (Murray 2018). Nevertheless, a growing self-proclaimed 'radfem' (radical feminist) movement in Brazil is following its northern hemisphere counterparts in routinely accusing sex worker activists of law breaking, pimping, and receiving funding from shadowy 'sex industry' mafias. Such accusations were recently levelled against one of the authors of this paper by a local radical feminist lawyer, who used the pages of a popular women's magazine to claim that said author was a pimp (Gonzalez 2016).

Meanwhile, mainstream Brazilian feminism is reluctant to engage with prostitution (and prostitutes) due to the divisive nature of the topic in feminist circles. As authors such as Adriana Piscitelli (2012), Sonia Corrêa and José Miguel Nieto Olivar (2010) have pointed out, prostitution didn't much appear on the feminist agenda in Brazil until after the turn of the century. Second wave feminism in the country prioritized the struggle against the military dictatorship during the 1970s and 1980s. While some feminists became interested in the then-nascent prostitute rights movement, protagonised by Gabriela Leite and Lourdes Barreto, by and large Brazilian feminism ignored the question. Providentially, this also meant that Brazilian feminism avoided the worst excesses of the 'sex wars' that rocked the feminist anglosphere during those decades.

This situation changed with the turn of the century, however, as first 'sexual tourism,' then 'trafficking of persons' developed into full blown moral panics in Brazil - panics that became indelibly associated with prostitution in the public mind and in a large portion of the feminist political sphere. As the first decades of the $21^{\text {st }}$ century passed, Brazilian feminism became increasingly polarized on the topic of prostitution and ever more reluctant to allow even marginal spaces in which to discuss it in neutral or positive terms. As feminist leader Maria Amélia of the União de Mulheres de São Paulo puts it, 'every time we discuss prostitution, we fight amongst ourselves and fight with the whores as well, so it's better not to discuss it, right?' (cited in Skackauskas and Nieto Olivar 2010: 5).

This withdrawal from debate may have helped to maintain feminist unity, but it has 'thrown prostitutes under the bus', particularly during a decade when feminism became increasingly incorporated as part of the State apparatus in Brazil (Murray 2018). As a result, few funds were made available to prostitutes' organizations via state associations, even as prostitutes' demands have become increasingly pushed out of feminist debates. It should also be remembered in this context that the George W. Bush Administration in the USA made those who received money from USAID swear an oath that they would not 
support any organizations or activities that sought to decriminalize or legalize prostitution (Leigh 2013).

This has made it increasingly harder for Brazilian sex worker associations to gain material support from international sources. Throughout the first decades of the $21^{\text {st }}$ Century, then, Brazilian prostitutes' rights organizations and their associated allies in academia have found themselves increasingly hamstrung when it comes to producing scientific data regarding sex work in Brazil and transforming this data into effective public policy.

By contrast, relatively copious funding has been made available in Brazil to those who study 'human trafficking,' particularly if they take the a priori approach that it is a major problem and cast their research to generate as great a number of cases as possible. ${ }^{6}$ Meanwhile, the country's sex worker associations (which have never been invited to participate as full-fledged partners in these sorts of rarely peer-reviewed surveys (Blanchette 2012)) have been reduced to passing the hat to keep the lights on in their (sometimes squatted) headquarters. In Europe and North America, the situation seems to be worse, particularly in the USA where prostitution is largely criminalized. To hint that sex worker organizations are as well funded and supported as the global rescue industry (Agustin 2007) and its anti-sex work allies is simply ludicrous.

In Brazil, then, feminist discussion of sex work (always a minor topic of interest and never a central theme for debate) has been almost completely marginalized except for discussions about prostitution as exploitation and violence. Ongoing moral panics regarding sexual tourism, human trafficking, and child sexual exploitation have potentialized fear of and revulsion towards prostitution in many feminist circles and radical feminist calls for criminalization of sex work are thus finding much more space and larger audiences than ever before. Put in simple terms, hegemonic feminism in Brazil seems unwilling to listen to sex workers at a time when they are being attacked by a small but loud minority within feminism.

What is worse, active sex workers face stigma and the threat of violence when they speak up. In June 2016, the Rio Slut Walk (Marcha das Vadias) hosted a debate on sexual tourism involving four active sex workers. A local feminist lawyer immediately threatened the women with legal charges of 'supporting criminal activity'. The women's Facebook pages were denounced and closed down. Their personal data, birthnames, and documents were publicly revealed. Finally, their supporters were slandered and physically threatened (Observatório da Prostituição 2016).

The same sort of tactics that anti-feminists use to attack people like Anita Sarkeesian ${ }^{7}$ (Valenti 2015) are routinely employed against 'out' sex workers - often by people who describe themselves as feminists. And while pro-criminalization activists might be the target of similar behaviour, there is one critical component of 'equivalency' that is missing: anti-prostitution activists are not criminalized. They are not subjected to high rates of violence because of how they make their living. Their freedom is not threatened by their activism. When someone like British anti-sex work journalist Julie Bindel receives threats, she knows that she can go to the police without risk to her life, liberty, or reputation. When women who sell sex attempt to do the same thing, even in countries where prostitution is 
not criminalized, they do not have that same privilege. Any interaction with the police can result in rape, extortion, imprisonment, or - more likely - moral and emotional violence.

Thus, one of the major problems sex workers face when attempting to create social justice for themselves is the belief that there are two equal sides to the debate regarding prostitution when this is not the case. This inequality is founded upon pornophobia or whorephobia: the fear of, aversion to, or discrimination against women who sell sex. Whorephobia is not simply a rhetorical term: it is a structuring fact of life. Unpacking and analysing it of primary importance in creating social justice for sex workers.

In Brazil and Argentina, one of the ways sex worker activists and their allies have been tackling whorephobia and the exclusion of sex workers' voices from feminist circles is through the development of putafeminismo (literally, whorefeminism). This does not follow the common accusation that sex worker rights activists 'think sex work is empowering. Apparently originating in Argentina, ${ }^{8}$ putafeminismo is based upon a Marxist analysis of labour in which work is understood to be alienating and a form of domination, but also a potential field for political organization and social struggle. In this understanding of prostitution, sex work is 'empowering' only to the degree that, like other work, it furnishes a common experiential basis for socio-political mobilization. This is alloyed with a feminist analysis of gender relations that sees prostitution as only one of a series of interlinked positions in which women are subordinated and pushed to exchange sexual and/or affective labour for sustenance and survival. Putafeminismo sees underpaid service sector work, marriage, and prostitution as equal parts of a capitalist, patriarchal complex and questions why only one part of this tripod - the open sale of sex - is criminalized and/ or reviled. In the words of sex worker and putafeminista intellectual Monique Prada (cited in Drummond 2017)

Basically, prostitution is something that common prejudice says no woman should want to be involved with - but still, millions of women have done it for centuries. It might be that it is far from being the worst thing in the world for women, but there is an entire society working hard to make it horrible... And there is a class of people - and I belong to this class - for whom selling sex, cleaning bathrooms, or changing old people's diapers are the work that is possible for us. This is dignified work and it is what we do. Unfortunately, in the society in which we live, we need to remember that not all people have the same horizon of possibilities which permit them to stay away from abusive bosses. Even so, we continue living and making the choices which are within our reach.

Key to putafeminismo's understanding of sex, work, and women is the attempt to recover not just the word, but the concept behind whore. This is the result of dialogues between sex worker activists and feminist and work theorists, many of whom come from the ranks of academia (and, it should be noted, it is also the result of a growing number of sex worker activists who are also academics or academically trained). The use of prostitute or 
even whore by Brazilian sex workers as a self-descriptive is probably one of the habits that most shocks Western European and North American feminist sensibilities. Indeed, it even ruffles feathers among allied sex worker rights groups in the northern hemisphere. It is thus worth taking a brief look at the etymology of this word in order to ask why is so rankles?

\section{Whorish etymologies}

Linguistically, the origins of 'whore' are fairly clear. Its proximate root is the Germanic word horaz, which means 'one who desires.' Further back, it is rooted in the Indo-European $k a$ and karo, meaning 'dear', and which gave Latin carus and Portuguese caro (Raccioppi 2009; Harper n.d.). The Portuguese puta apparently comes from the female conjugate of the Latin puttus, meaning a young person (Harper n.d.; Buich 2016), particularly one of low social status who can be found 'in the street.'

These roots are telling. The English case etymologically links 'whore' to female desire. The Portuguese case associates the word with young, lower class women, publicly displaying themselves outside of the family context. These roots betray what is really at issue in today's insulting use of the terms: female independence. The horaz is a woman who desires, who is not content with her lot in life, who actively seeks to put her interests first. The putta is a girl in the streets in a deeply patriarchal society, participating in public life without the protection of a family. In both cases, it is the independent doings of women, without reference to men or family, that is at the root of the problem. And in both cases, the threat this independence represents ends up being couched in sexual terms.

As several authors have pointed out (Ortner 1974, 1978; Graeber 2011; Ringdal 1997; Lerner 1980, 1989), women's independence - and particularly their sexual independence - seems to have been curtailed wherever market-based economies take hold. As David Graeber (2011: 178) puts it

It has always been something of a scandal for those who like to see the advance of science and technology, the accumulation of learning, economic growth - 'human progress', as we like to call it - as necessarily leading to greater human freedom, that for women, the exact opposite often seems to be the case. Or at least, has been the case until very recent times. A similar gradual restriction on women's freedom can be observed in India and China. The question is, obviously, Why?

Graeber proposes that the rise of patriarchy was a reaction to cycles of increasing indebtedness and mercantilisation accompanying the militarization of civilizations, which threatened to turn all human relations into commodities. Under this regime, relations of domestic authority literally became property relations, being that a man's wife and children could be used as surety on his loans. In ancient Mesopotamia, then, prostitution which had previously been seen as a sacred act - became more and more associated with debt slavery, provoking 'a horrified reaction on the part of the (male) winners of the eco- 
nomic game, who over time felt forced to go to greater and greater lengths to make clear that their women could in no sense be bought or sold' (Graeber 2011: 179).

Graeber, following Gerda Lerner (1989), thus claims that 'patriarchy as we know it seems to have taken shape in a see-sawing battle between the newfound elites and the newly dispossessed [and indebted]' (Graeber 2011: 184). As prostitution became synonymous with slavery, it became necessary to differentiate ever more sharply between 'respectable' women whose bodies could not be bought or sold and 'unrespectable' slaves/ prostitutes who were chattel. The 'world historical defeat of women' referred to by anthropologist Gayle Rubin (1975: 157-158) thus seems to have been consolidated through an expropriation of women's sexuality. In the regimes created by the dawn of mercantile civilizations, a woman could either be a slave/prostitute, with no legal right to her body, or 'free and respectable', which in David Graeber's words meant having her physical person 'hidden away and permanently relegated to some man's domestic sphere' (Graeber 2011: 185). In either case, women's bodies and sexuality were not their own.

Graeber's analysis casts new light on explanations of what whore/puta means and who the words apply to. A woman who has her own desires is anathema in classical patriarchal society: either she is under a man's authority in the sphere of the family or any man can do with her as he will. To talk of women having rights outside of the family is utter nonsense. Her respectability, which in the final sense means that she has wishes or desires that must be respected, is conditioned upon the submission of these to male domestic authority. Likewise, the young women exposed on the streets without her family can only be a nonperson who has nothing that must be respected.

It is worth reflecting upon that today's 'West' (however it is defined) is descended from the classical patriarchal civilizations of the Mediterranean basin (Schüssler-Fiorenza 1993) and that the laws that governed women's respectability are not that far in the past. Indeed, many are still with us today. The key difference between respectable women and whores still revolves around questions of social control of female sexuality. Even in supposedly progressive Sweden, with its feminist-oriented laws prohibiting the purchase (but not the sale) of sex, women who sell sex are considered to be fundamentally damaged goods: sick at best, criminally perverse at worst. And while they cannot be imprisoned for prostitution, they can be denied rights and benefits, housing, and access to their children, and whereas men revealed as prostitutes' clients can be fined, women revealed as prostitutes or even ex-prostitutes can lose their jobs (Edlund and Jakobsson 2017).

Across the 'Western' world, the State has the job of keeping whores out of the way of respectable women and families, maintaining the same general distinction that first became visible 3200 years ago in Mesopotamia. It is true that the sphere of activity for respectable women has expanded beyond the limits of the family and that these women are now recognized as subjects. However, part of the price of this relative expansion of women's rights seems to have been the maintenance of the old duality between respectable women and whores and the progressive disenfranchisement of the latter.

Ironically, it seems that it is precisely the most liberated and economically successful segments of the 'West's' female population who have become the most avid pornophobes. ${ }^{9}$ 
To paraphrase David Graeber's comments on ancient Mesopotamia, in this age of increasing mercantilisation and debt, a horrified reaction seems to be occurring on the part of female winners of the economic game, who increasingly feel forced to go to greater and greater lengths to make clear that they, as women, can in no sense be bought or sold. As is always the case in moments like this, the boundaries between 'good' and 'bad' women must be reinforced. As today's good woman is allowed a certain degree of sexual autonomy, her symbolic counterpart is logically and increasingly the whore who is imagined as abject, voiceless, without agency, and deserving of any intervention the State sees fit to impose upon her, as long as it is wrapped in the rhetoric of rescue and salvation. Although the whore is presented as a woman who exchanges sex for money, the association of this image with certain physical and cultural types of women (who are usually quite distinct from their societies' female elites) means that the surveillance and repression activities designed to punish and control whores have the side-effect - perhaps even the principally desired effect - of disciplining a much larger female population.

Whore and puta are thus terms whose stigma is a function of the world historic defeat of women, ongoing since the Bronze Age. Unlike many other sex-oriented offensive terms, the words are not offensive in their origin. Queer, for example, indicates abnormal deviance. Faggot's etymological roots are less clear, but the consensus is that, at least as applied to gay men, the term was meant to be insulting from the start. ${ }^{10}$ By contrast whore - and to a lesser degree puta - contain etymological signifiers of female agency and independence. Apparently, it is precisely the female deviance from patriarchal norms which these terms describe than make them offensive and this is why attempts at recovering these terms today should not be rejected a priori.

Lots of ink has been spilled regarding the proper term for those who exchange sex for money. In the English-speaking world, people who support the decriminalization of the sale of sex tend to refer to it as 'sex work.' Those who wish to abolish it and/or support its criminalization call it 'prostitution' or even 'rape,' 'slavery,' 'human trafficking, or other emotionally charged terms. Many people involved with Brazil's prostitution movements call it 'prostitution' or 'sex work' interchangeably and call the people who do it 'prostitutes' (prostitutas), 'sex professionals' (profissionais do sexo), or 'whores' (putas). This etymological flexibility is primarily a legacy of Gabriela Leite, the legendary Brazilian prostitutes' rights activist, who was well aware of the linguistic origins of puta and whore, like many sex worker activists of the 1980s and 1990s.

Gabriela was sceptical about what she called 'politically correct language', which she saw as distracting from the prostitutes' movements' main focus: people who sold sex and the stigmas and violence they faced. During our first meeting with Gabriela back in 2005, she told us that 'we need to remain putas and prostitutas, even though we are properly profissionais do sexo, because that's what society calls us.'

We are never going to get the common person to call us anything else. To try is a waste of time and resources. What we need to ask is 'Why is it a bad thing to be a puta?' That puts the finger squarely into the wound, doesn't it? There's no getting around that question un- 
less you want to be a moralist, and once people openly assume their moralism.... ah, then we can talk and maybe change minds! (Gabriela Leite, personal interview by the authors, November 2005). ${ }^{11}$

Although many people who sell sex in Rio de Janeiro describe themselves as 'sex professionals' (but hardly ever 'sex workers'), others repudiate this term, as they don't feel that selling sex should be a job. A few of these agree with those who wish to abolish prostitution that sex work is a nasty, often violent, often degrading, sexist makeshift which wouldn't exist in a truly egalitarian society (the ones whom we've talked to differ from sex work abolitionists, however, in that they do not wish to see the sale or purchase of sex criminalized.) More believe that as soon as something is defined as 'work' in Brazil, taxes and the State follow, much to workers' detriment. Even more do not want to be officially registered as a sex worker, which they feel would be an inevitable result of regulating the sale of sex as work.

But almost all Brazilian sex workers we know use 'prostitute' and 'whore' (along with an enormous list of synonyms) to describe themselves and others who sell sex. These are the emic terms most commonly encountered wherever Brazilians who sell sex gather.

The movement that Gabriela Leite helped found in 1987 - The Brazilian Prostitutes' Network (BPN - Rede Brasileira das Prostitutas) - has largely embraced this terminology. Its members want those who sell sex to be recognized as citizens and workers, but are fully aware that they are labelled as - and, indeed, label themselves as - prostitutes and whores. In fact, Lourdes Barreto, a 76-year-old co-founder of the BPN, has 'I am a whore' tattooed on her right forearm (see Figure 1), which she shows to anyone who she feels is missing the point.

Figure 1: Lourdes Barreto with tattoo 'Eu sou puta'/'I am a whore'

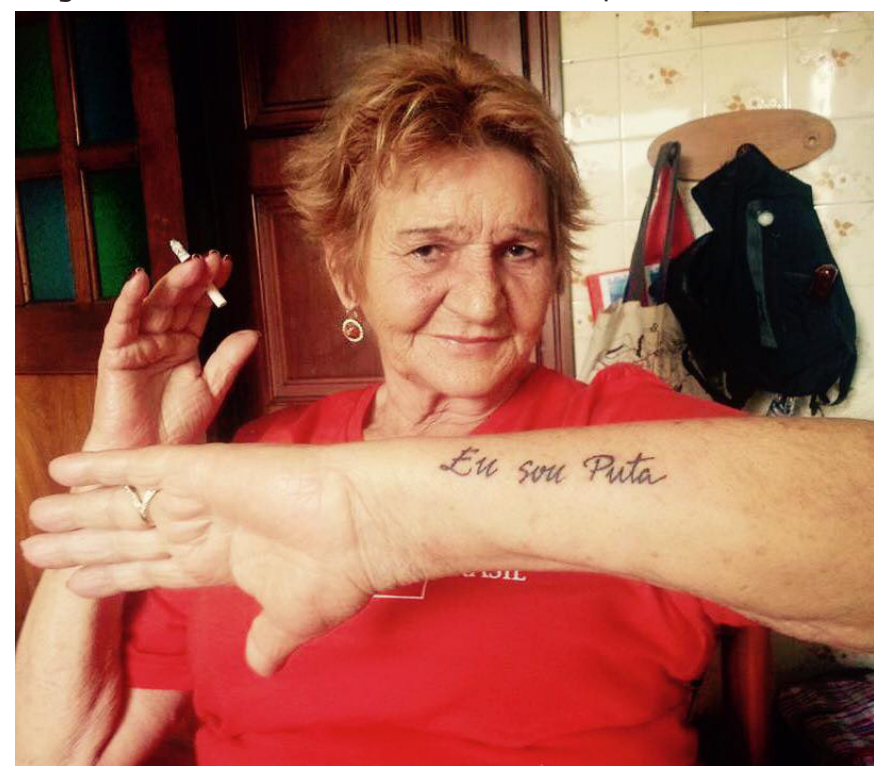

Source: Facebook page of Lourdes Barreto (2018) 
Although it has become acceptable in US and European sex working circles to use 'whore', the Brazilian situation differs - at least for now - in that allies can employ the term, as long as they do so respectfully. In this sense, then, 'whore' seems to mark out a philosophical or ontological position (what Gregory Mitchell (2016) terms 'the ontology of the whore'), rather than a cohesive group identity, à la Frederic Barth (1969). If one attends the demonstrations and events organized by the Brazilian Prostitutes' Movement, one will often be exhorted to think of oneself as a whore. As sex worker and city councilwoman Indianara Siqueira put it at a recent public event:

You're all whores too, you know. You don't do what you do because you love your job or are loyal to your boss. You do it for money. Those of you who are teachers, you don't get out of bed at 5 AM and bus to work because you love your students and are dedicated to your profession: you do it for a salary. Sure, you may ALSO love your students and occasionally even your job. Even whores occasionally cum. But dinheiro na mão, calcinhas no chão. ${ }^{12}$ Every worker is a whore and every whore, a worker (Siqueira 2017).

This insistence on the universality of whoredom among those who earn salaries invites those who do not sell sex to empathize with those who do as members of what Marx would call the 'working class' and to concentrate on the problems of whores (more generally) and the problems of whores who sell sex (more particularly) rather than on prostitution as a problem, per se. This has created a multifaceted and flexible puta politics (to use the term coined by Laura Murray (2014)) in which prostitutes point to themselves as stand-ins for a vast variety of Brazilian urban populations that are being marginalized in the neo-liberal 'branded city', and for a working class that is rapidly being stripped of its rights, benefits, and pay. By exploding the classical liberal notion that work is a moral category - something done for love or as a vocation, which ennobles the worker - puta politics builds bridges to other urban and working-class experiences while attempting to reclaim space in the city for free and democratic public life (Simões 2016).

This, then, lies at the root of putafeminismo: an embracing and democratization of puta/whore which seeks a creative and intersectional approach to feminism, fully aware of the immense divisions within that political field (and among women in general) regarding sex work/prostitution. It does not see these divisions as neutral or evenly balanced, but rather as being constituted by lived experiences of class, citizenship, and race among women - lived experiences which create privileges and exclusions. It is critical of what Elizabeth Bernstein calls 'carceral feminism' and 'militarized humanitarianism,' which attempt to create social justice via increased surveillance and imprisonment (Bernstein 2010). It rejects the sexualization promulgated by post-liberal state-led, NGO-managed human security politics of the global south, which Paul Amar describes as 'putting gender in its "traditional place" and rescuing the family from 'perversions of globalization' in the cultural domain (Amar 2013). It recognizes that the disciplining and punishing activities of society inevitably select certain bodies, certain persons, as their focus. It seeks to alert 
feminists to the practical and quotidian effects of this and what they mean in terms of social justice for sex workers.

If the main thing that needs to change in Brazil on the road to a social justice agenda for sex workers, then, is the de-stigmatization of prostitution, putafeminismo postulates that the best way to do this is by supporting those sex workers who are publicly out, creating visibility for sex work as a whole, and by tying sex work activism into a large network of diverse supporters active in other social justice issues - particularly those related to feminist issues, workers' rights, LGBT rights, and anti-carceralism. The goal is to help sex workers (re)create their own democratic movements and speak in their own name.

\section{Puta political theory}

Putafeminismo appears in the context of a feminism that has been, to a significant degree, 'captured' by the State, as described by Laura Murray (2018). This is a feminism that increasingly flirts with carceralisation (Bernstein 2010), after a long flirtation with state power, which appears to have largely abandoned sex workers. Putafeminismo is an intersectional approach, much in the same manner of the black feminisms that appeared during the second wave of feminism. It arises because the intersection of woman and sex worker creates specificities that, ironically, are largely unexplored by many of feminism's more hegemonic variants.

Feminism is, of course, a diverse ideological field and there are feminisms that are and have been very supportive of sex work and sex workers. The Pagú Gender Studies Nucleus at the state University of Campinas, in São Paulo, is an excellent example of this tendency, working with sex workers on a local, regional and national level to bring them into feminist debates and, more importantly, into policy making. But the more hegemonic strands of feminism - and, in particular, the sorts of feminism that end up as part of State agencies, laws, and agendas - tend to ignore the specificities of sex work, seeking to solve the problem of prostitution rather than attend to the demands of prostitutes. As Ola Florin (2012: 273) puts it in her analysis of Swedish anti-prostitution laws, in the eyes of this sort of feminism, 'prostitution generates victims by analogy and only from a structural point of view.'

Female sex vendors are victims in their capacity as women due to the bare existence of men's purchases of women's sexual services. Seen this way, a woman is a victim of violence so long as at least some men buy sex from women, irrespective of whether or not she herself enters or exits the sex trade. Female social or health care workers are as much a victim as the woman selling sex who they are trying to assist (Florin 2012: 273).

This structural understanding of the sale of sex creates a dynamic within much of feminist thought where prostitution is largely (if not exclusively) understood as violence against women as a collective, with individual women in prostitution positioned as either 
victims without agency or as actively contributing to that violence (Florin 2012: 278). An extreme instance of this view can be found in British radical feminist intellectual Julie Burchill's (1987: 9) declaration that 'when the sex war is won prostitutes should be shot as collaborators for their terrible betrayal of all women.' While few feminists would go to Burchill's extremes, few feminists nonetheless seem to be able to get beyond employing the old clichés of 'selling the body' and 'objectification' as primary interpretative lenses. Unfortunately, objectification and selling the body are problematic metaphors when applied to prostitution.

As we have described in detail elsewhere (Blanchette, Camargo and Silva 2014), following feminist theorist Evangelia Papadaki (2007, 2010), much of the second wave of feminism's thoughts on sexual objectification - and particularly the views of radical feminists such as Catherine MacKinnon and Andrea Dworkin - employ Emmanuel Kant. Kant's views on this matter, however, have some very curious lapses and contradictions, largely ignored by these feminist scholars. Most particularly, Kant had no problem with humans using other humans as instruments of their will, as long as this use is temporary and consensual. In Lectures on Ethics, the philosopher specifically claims that 'man can certainly enjoy the other as an instrument for his service; he can utilize the others' hands and feet to serve him, though by the latter's free choice' (Kant 1997: 155). However, Kant then goes on to state that 'we never find that a human being can be the object of another's enjoyment, save through the sexual impulse.' Sex, for Kant, somehow transforms the instrumental use of another person from something that is ethically acceptable into something that is not. It is important to note, in this context, that Kant never describes how or why this is so and it is probably significant, in this respect, that he died an 80-year-old virgin (Strathern 1996: 12). In other words, the Kantian notion of sexual objectification seems to be based on a deep ignorance of the sexual act per se - an ignorance that may, in fact, be rooted in a fear of sex itself (and sex outside of the bonds of marriage, in particular).

This Kantian notion of sexual objectification is further potentialized in terms of its pornophobia by the metaphor of selling the body, also utilized by Kant and absorbed into social scientific thought by theorists such as George Simmel (1971). This metaphor has become so prevalent in discussions of prostitution that it is routinely employed a synonym for prostitution. However, even the slightest thought about this metaphor should make its limitations obvious for, as sex worker rights leader and putafeminista Indianara Siqueira puts it, 'Honey, if I sold my body, there'd be nothing left here to talk to you.'

Selling the body presumes objectification and alienation, but is this necessarily what happens when sex is sold? Tellingly, many feminists who write about prostitution using these terms seem to have actually spent very little time in brothels, watching sex workers work. As Indianara Siqueira points out, her body obviously has not been passed on as alienated property to another human being simply because she sells sex and this, in fact, is something that almost all sex workers we interview emphasize.

Sex, sold, is an intense and constant process of dialogue and negotiation, one in which the woman has forgone the protection of the customary 'rights' and considerations accorded to wives and girlfriends. It is dangerous. It is fraught. However, it is no more (or 
less) necessarily 'alienating' than marriage or a Saturday evening hook-up. It often involves the same sort of negotiations, with women asserting the right to their body, setting lines and demanding that these be respected. These demands may not always be respected in prostitution, but they are likewise often not respected in marriage or casual unpaid sex. This is a problem rooted in sexism and patriarchal values, not in prostitution per se.

Brazilian prostitutes, in fact, have a name for the sort of man who does not respect the limits they set: psychopath. He is clearly distinguished from clients. In the words of one of our sex working interlocutors, 'A client negotiates in good faith and pays you for sex.'

He stays to agreements and respects your decisions. A psychopath does not want sex. He wants to hurt women and he attacks prostitutes because he can. People do not think that a whore can be raped and when we are, they do not care (Anonymous, personal communication, August 2016).

When feminists focus on sexual objectification and selling the body, while ignoring or diminishing what is key in every other point of Kantian ethics - consent and what we today would call agency - they inadvertently end up reifying and foregrounding the position of the psychopath who believes that initial consent gives him untrammelled and unconditional access to the bodies of women. Every sex worker we have ever talked to emphatically denies this point of view. Ironically, however, when one reads many feminist analyses of sex work, it often seems that these authors are peering, voyeuristically, over the psychopath's shoulder, ignoring entirely what the woman who sells sex is doing or feeling. This problem occurs even in the work of those feminists who are generally considered to be sex worker allies.

As a concrete example of this way of thinking, let us take the views of Patricia Hill Collins, a Black feminist well-respected by many Brazilian putafeministas, not the least for her popularization of Evelyn Brooks Higginbotham's concept of respectability politics, which has become a touchstone in many putafeminista debates about femininity, class, and race (Collins 2004; Higginbotham 1992). As Mireille Miller-Young points out in her ground-breaking book on black women in porn, A Taste for Brown Sugar (2014), Collins understands pornography and prostitution to be inherently violent and dangerous, ${ }^{13}$ situating black women involved in the sale of sex (or in the production of sexual images) to be totally alienated beings who are separated from and do not control their bodies (Collins 2000: 123-144). She describes these women in exactly the same ways that Florin critiques above, as objects without agency embedded in a motionless social structural geometry, and not as thinking, feeling subjects.

Notably, Collins bases her analysis regarding fragmentation, domination, objectification, and the alienation of the body in sex work on Scott McNall's (1983) work on pornography, and not on contact with sex workers. While we might agree with her and McNall that male consumption of sex (via pornographic images or female bodies) often displays a will towards the domination, fragmentation, and reduction of women's bodies, domination, fragmentation, and reduction are not necessarily created by the sale of sex any more 
(or less) than they are by forms of sexual exchange that don't involve money. It bears repeating (with apologies to George Simmel): there is no magical quality of money that transforms women's bodies into alienated commodities when money is exchanged for sex. Patriarchal relations and sexism are responsible for this fetishization and for the violence against women in intergender sexual relations, not coins that may slip from hand to hand before, during, or after sex.

The main problem with the position taken by Collins and McNall, however, is that by focusing on supposed structural and symbolic concerns, it ends up prioritizing the agency and point of view of the psychopath and not of the sex worker. It thus becomes complicit in the erasure of sex workers as subjects. From years of listening to sex workers talk about what they actually do when they sell sex, we can assure readers that they are most certainly not complicit in transforming male fantasies into realities of domination, objectification, and fragmentation. These are some of the things we understand most sex workers to be doing when they are in the 'open and fragmented' position Scott McNall and Patricia Hill Collins understand as basic to prostitution:

1. They are surveilling the client.

2. They are enforcing safe sex procedures and engaging in safe sex education.

3. They are evaluating their body and the client's body for cleanliness and signs of disease or discomfort.

4. They are preparing themselves to use violent sanctions to guarantee their bodily autonomy.

5. They are keeping track of the time.

Most of all, when sex workers are working providing sex, they are constantly making sure that what is happening is something they agree to do. In other words, they are actively patrolling and enforcing their consent.

Nothing in the above description should be foreign behaviour to any sexually active adult woman. And yet far too many feminist theorists who have never engaged in or observed sex work, who probably do not know many (if any) sex workers, and who have certainly not listened much (if at all) to what these women have to say, feel entirely justified in glossing the interactions between men and women in paid sex as 'selling the body' and as portraying this behaviour off as diametrically opposed to what they do as supposedly liberated and empowered women. And yet what we have heard from sex working women, time and again, is that the risks of intergender heterosexual exchange do not increase in severity or frequency because money is exchanged. Rather, because the sale of sex is stigmatized under patriarchal relations, women who engage in it become overdetermined targets of abuse.

Ultimately, the view of prostitute women as beings without agency enmeshed in social structures beyond their control reiterates, in the field of gender, the sort of position roundly criticized by Brazilian critical race scholar Denise Ferreira da Silva in the field of race. In this view of the world, humanity is divided into two types of beings: rational (wo) man who is a self-determined subject and 'outer-determined' others whose minds and behaviours are driven by the conditions of their surroundings (Silva 2007). Here we have 
a dichotomous divide between two sorts of women. On the one hand, the feminist analyst who, although oppressed by sexism and patriarchy, apprehends these for what they are and seeks to dismantle them; on the other, the abject prostitute who is senseless of and/or powerless towards sexism and patriarchy and can only be 'saved' from them through the actions of others. This dichotomy seems to re-inscribe, in post-modern form, the older dichotomy between good and fallen women, with agency replacing purity. The key distinction still turns, as ever, on the variable of women's 'proper' sexual behaviour.

Putafeminismo challenges this dichotomous framing of sex work and it seeks to do it in the here-and-now, and not in some imagined post-revolutionary utopia. It seeks to create a feminism that is useful and understandable to women who sell sex and which allows them to speak for themselves, rather than be spoken of.

\section{Puta politics}

In Brazil, we have found that an alliance of sex work activists, academic researchers, politicians and journalists, working with a larger population of (as yet) un-politicized prostitutes is a very effective way to produce and publicise data about prostitution and bring it to policy makers' eyes, push feminism into dialogues with whores, reduce stigma and whorephobia and thus create the necessary preconditions for social justice. By cultivating trust among and cooperation with local sex workers, researchers are able to deeply investigate and analyse the problems these women face, as well as thickly describe the weft and warp of their lives. Sex worker activists can then take this data and transform it into concrete proposals that can be represented in policy making circles by allied politicians. Finally, journalists can present the data and issues in a way that is accessible to the public at large. By making it difficult to ignore sex workers' voices, society is pressured to deal with whores' issues rather than the 'problem of prostitution.' As women who sell sex begin to see pro-active whores articulating demands, they, in turn, become more politicized.

The above normative description shouldn't be seen as detailing rigid or hierarchical positions: in this alliance, a given person may wear many different hats or move from one position to another. Two brief examples of the many projects that Prostitution Policy Watch (PPW) and Davida (two umbrella organizations that work together in Rio de Janeiro) organized around the 2014 football World Cup and the 2016 Olympic Games should give readers a better notion of how such alliances work.

The first is Dr. Laura Murray's project 'O Que Você Não Vê.' This brought together photojournalists and artists who taught a group of sex workers to operate donated digital cameras and properly frame and shoot photos. The women were recruited from the PPW's ongoing ethnographic and research projects in Rio's brothels and street scenes and by Indianara Siqueira, a trans city councilwoman and sex worker activist. During the Games, Murray's group took over 5000 digital images that registered everything from the women engaging in oral sex to feeding their cats - images that maintain the degree of anonymity that the whore researchers feel comfortable with. These images will be curated by their producers them in virtual and physical exhibitions. A side effect of this project is that 
many of the women who live in the Casa Nem trans squat in Rio's bohemian Lapa district now refuse to let journalists photograph them. Instead, they themselves will take whatever photos they feel comfortable with and then sell them to the journalists.

The second project is journalist Julie Ruvolo's Red Light Rio (n.d.). Julie came to Brazil in 2012, and Davida activists and allied researchers took her into the city's brothels, where Julie eventually made her own contacts, spending three years in close proximity with the women of the Vila Mimosa red light district. Ruvolo created her site around interviews with researchers, activists, and sex workers, giving links to academic papers for readers who wanted more or deeper information. She became so trusted by many of the women in 'VM' that she was able to videotape their stories. Julie also put many of her interlocutors in contact with Davida and the PPW, who then recruited some of them for the abovementioned Olympics photography project. Several of her interlocutors are now engaged in political activities focusing on prostitutes' rights. Ruvola also has published the PPW's research findings regarding prostitution and mega-events on her site.

These two projects and many more are founded upon the legacy of the late Davida President Gabriela Leite's Daspú line of clothes. Daspú was created in 2005 to be a political and fund-raising project. It brought together prostitutes, sex worker rights activists, researchers, designers, artists, celebrities, and journalists to help create and market a line of clothing by and for prostitutes. Daspú fashion shows would run in Brazil's red-light districts whenever major fashion events took place. Prostitutes shared the catwalk in a promiscuous mixture with professors, housewives, journalists, students, and celebrities, wearing clothing that highlighted sexuality (in the same way that regular fashion shows do), but which also displayed pro-prostitutes' rights, decriminalization and anti-HIV messages. The highlight of the now considerable Daspú fashion line is a wedding gown made of motel sheets decorated with sexual positions. Many of Davida and the PPW's current cadre met and were mobilized through Daspú.

The point of Daspú fashion shows was to ask audiences the following: 'Now that everyone is dressed in the same manner, can you tell who is a whore and who isn't? What is the fundamental difference between a whore's use of her body to gain money and a model's? Why is the one criminalized while the other is celebrated by high society?' Here, we can see the roots of putafeminismo sprouting and growing.

Feminists are a key group of potential sex worker allies. Yet, in spite of the fact that our country's sex work venues are eminently public and freely accessible, the large majority of feminists in Brazil have never been to a brothel. This doesn't stop them from imagining brothels, however. We have thus found that a very simple and easy way to break the impasse between feminists and prostitutes is to simply take the former to visit and talk to the latter. Once in contact with the diverse realities of prostitution and the humanity of the people who sell sex, it becomes very difficult to hold to dogmas. In particular, it becomes very hard to see prostitution as a faceless 'phenomenon' and prostitutes as victims without agency. This tends to push even the purist anti-sex-work activists towards attempts at solving the problems of the women who sell sex rather than solving the problem of prostitution - which no civilization, anywhere, at any time, has ever done. 
All of this activism and research, which has now been on-going for almost 20 years, has had concrete impacts upon Brazil's prostitution and anti-trafficking policies. It has achieved seats for Davida on the federal and Rio de Janeiro anti-trafficking committees, where the organization has had a major say in the recent overhaul of Brazil's anti-trafficking laws. These were changed specifically to avoid the equation of sex work with sexual exploitation and human trafficking (among other things). The putafeminista alliance that has grown up around Davida also used hard data collected during the 2014 World Cup to help convince the Brazilian state to avoid closures of sex work venues in the name of anti-sexual-exploitation, as had occurred in 2014, and instead concentrate on the labour exploitation of children, which had been endemic during the World Cup, but was largely ignored in the futile search for sexually exploited children.

In practical terms, however, the main barriers that Brazil's putafeminista sex workers face in attempting to (re-)construct their agenda for social justice are, frankly, material and financial. To our minds, then, the very best way that international agencies can work for social justice for Brazil's whores, at the present moment of economic crisis and reactionary political retrenchment, is through funding initiatives. In the final analysis, while the movements can do wonders with very little, nothing can be done with nothing.

\section{Notes}

1. Our research deals exclusively with cis-women who sell sex, although we dialogue intensively with other researchers (Gregory Mitchell, Larissa Pelucio, Michelle Agnoletti, Flavia Teixeira and Don Kulick, among many others) who investigate men, transwomen, and travestis, who sell sex. The present article concentrates exclusively on women who sell sex.

2. Pornae being, of course, the greco-latin word for whore, 'pornography' is 'writing about whores' and 'pornophobia' is, properly, 'fear of whores' and a synonym of 'whorephobia.'

3. Also useful is GAATW's analysis of the anti-trafficking panic surrounding mega sporting events (GAATW 2011) as a starting point for those who need more information. With regards to the use of bullshit in Brazil in discussions regarding prostitution and trafficking, see Blanchette (2012).

4. Leading Swedish sex worker activist Pye Jakobsson to quip: 'I don't understand. I am judged competent to make money. I am judged competent to have sex. But if I make money having sex, suddenly I am incompetent' (Pye Jakobbson, interview by authors, July 2017).

5. See, for example, the petition at https://www.change.org/p/amnesty-international-listen-to-survivorsreject-the-proposal-to-decriminalize-all-aspects-of-prostitution.

6. An excellent example of this can be seen in PESTRAF, the foundational study for Brazil's new state antitrafficking policies. We have undertaken an in-depth study of its many problems elsewhere (Blanchette and Silva 2012, 2014), which can be resumed as follows: the authors promiscuously mixed incompatible definitions of 'trafficking' in order to pad their study with as many supposed cases as possible and thus prove their a priori assumption that trafficking for sexual exploitation was an enormous problem in Brazil.

7. Anita Sarkeesian is a feminist social commentator who has been heavily attacked and harassed by so-called 'Men's Rights Activists' for her work on videogames' representations of women.

8. Argentine sex worker activist Georgina Orellano's forthcoming book, Puta Feminista. Crónicas de una Trabajadora Sexual can be read as the movement's opening broadside. Orellano's AMMAR (Associación de Mujeres Meretrices de la Argentina en Acción para Nuestros Derechos) has been crucial to kickstarting putafeminismo in South America, although there is some discussion as to whether or not the term itself originated in Argentina or in Spain.

9. Our experiences in Brazil demonstrate this, without a doubt. In a recent count of recognizably pro- 
criminalization feminists on Facebook sites linked to our country's prostitution debates, $88 \%$ were white. This, in a country that is over half black.

10. Faggot's most probable origin seems to be as an insulting term for the kind of marginalized old woman who was reduced to collecting sticks and firewood as a means of survival. Its application to gay or effeminate men is thus clearly meant to be to be insulting from the beginning (Morton 2005).

11. For more, see Laura Murray's interview with Gabriela at Um Beijo para Gabriela (2013).

12. Literally 'Money in hand, panties on the floor.' Idiomatically, 'No money, no honey'.

13. Although prostitution and pornography are, obviously, not one and the same thing, Collins seems to blend both together when talking about power relations, domination, objectification and alienation, using the same theoretical reference, McNall (1983), to deal with these issues in both fields.

\section{References}

Agustin, Laura. 2007. Sex at the Margins: Migration, Labour Markets and the Rescue Industry. London: Zed books.

.2010. "Important Enemies: Hating sex-work academics or hating research?" The Naked Anthropologist. At https://www.lauraagustin.com/important-enemies-hating-sex-work-academics-orhating-research [Accessed on 9 September 2017].

Amar, Paul. 2013. The Security Archipelago: Human Security states, Sexual Politics, and the End of Neoliberalism. Durham: Duke University Press.

Amnesty International. 2016. 'Amnesty International publishes policy and research on protection of sex workers' rights.' Amnesty International, 26 May 2016. At https://www.amnesty.org/en/latest/ news/2016/05/amnesty-international-publishes-policy-and-research-on-protection-of-sex-workers-rights/ [Accessed on 9 September 2017].

Barth, Frederik. 1969. Ethnic Groups and Boundaries: The Social Organization of Culture Difference. Longview: Waveland Press.

Bernstein, Elizabeth. 2010. 'Militarized humanitarianism meets carceral feminism: the politics of sex, rights, and freedom in contemporary antitrafficking campaigns.' Signs 36 (1): 45-72.

Blanchette, Thaddeus G. 2012. 'On Bullshit and the Trafficking of Women: Moral Entrepreneurs and the Invention of Trafficking in Persons in Brazil.' Dialectical Anthropology 36 (3): 107-125.

Blanchette, Thaddeus G and Ana Paula da Silva. 2012. 'On bullshit and the trafficking of women: moral entrepreneurs and the invention of trafficking of persons in Brazil.' Dialectical Anthropology 36 (1-2): 107-125.

2016. "Brazil has its eye on you": sexual panic and the threat of sex tourism in Rio de Janeiro during the FIFA World Cup, 2014.' Brasiliana - Journal for Brazilian Studies 4 (2): 411-454. At https://tidsskrift.dk/bras/article/view/21398 [Accessed on 9 January 2017].

Blanchette, Thaddeus G, G Camargo and Ana Paula da Silva. 2014. 'Idealismo alemão e o corpo alienável: repensando a 'objetificação' no contexto do trabalho sexual.' In S Simões (ed), Prostituição e Outras Histórias de Amor. Niterói: Editora UFF, pp. 101-121.

Buich, Nora. 2016. 'Origem da palavra 'puta.' Esquerda Diário. At http://www.esquerdadiario.com. br/Origem-da-palavra-puta [Accessed on 9 September 2017].

Burchill, Julie. 1987. Damaged Gods: Cults and Heroes Reappraised. London: Arrow Books. 
Collins, Patricia Hill. 2000. Black Feminist Thought: Knowledge, Consciousnees, and the Politics of Empowerment. London: Routledge. ledge. 2004 . Black Sexual Politics: African Americans, Gender and the New Racism. London: Rout-

Corrêa, S and J M Nieto Olivar. 2010. 'The Politics of Prostitution in Brazil: Between 'state neutrality' and 'feminist troubles." Mimeo.

Drummond, Maria Clara. 'Voz do feminismo no Brasil, a prostituta Monique Prada fala para a Revista J.P' Glamurama, 16 January. At http://glamurama.uol.com.br/voz-do-feminismo-no-brasila-prostituta-monique-prada-fala-para-a-revista-j-p/. 2017 [Accessed on 12 March 2017].

Edlund, C and P Jakobsson. 2017. Then Again They are not Totally Stupid, Either. Stockholm: Rose Alliance.

Farley, Melissa. 2004. Prostitution, Trafficking and Traumatic Stress. Binghamton: Hawthorn Maltreatment and Trauma Press.

Frankfurt, Harry G. 1986. 'On Bullshit.' Raritan Quarterly Review 6 (2): 81-100.

Fraser, Nancy. 2009. Scales of Justice: Reimagining political space in a globalizing world. New York: Columbia University Press.

GAATW. 2011. What's the Cost of a Rumor? A Guide to Sorting out the Myths and the Facts about Sporting Events and Trafficking. At http://www.gaatw.org/publications/WhatstheCostofaRumour.11.15.2011.pdf [Accessed on 9 September 2017].

González, L. 2016. 'Empoderadas ou Vítimas?' TPM: Trip para Mulheres. At https://revistatrip.uol. com.br/tpm/prostitutas-empoderadas-ou-vitimas [Accessed on 3 August 2018].

Gould, S J. 1981. Mismeasure of Man. New York: Norton and Company.

Graeber, David. 2011. Debt: the First 5,000 Years. New York: Melville House.

Harper, Douglas. s.d. 'Whore n.' Online Etymology Dictionary. At www.etymonline.com/index. php?term=whore [Accessed on 9 September 2017].

Higginbotham, Evelyn B. 1993. Righteous Discontent: The Women's Movement in the Black Baptist Church, 1880-1920. Cambridge: Harvard University Press.

Jordan, Ann. 2012. 'The Swedish Law to Criminalize Clients: A failed experiment in social engineering. Center for Human Rights and Humanitarian Law, Issue Paper No. 4. At http://www.fair-paysex. de/fremddateien/Issue-Paper-4\%5B1\%5D.pdf [Accessed on 9 September 2017].

Kant, Immanuel. 1997. Lectures on Ethics. Cambridge: Cambridge University Press.

Leigh, C. 2013. Just Sign on the Dotted Line: The Anti-Prostituytion Loyalty Oath. At https://vimeo. com/43262622 [Accessed on 3 August 2017].

Lerner, Gerda. 1980. 'The Origin of Prostitution in ancient Mesopotamia.' Signs 4 (3): 173-198.

1989. The Creation of Patriarchy. New York: Oxford University Press.

Miller-Young, Mireille. 2014. A Taste for Brown Sugar: Black Women in Pornography. Durham: Duke University Press.

McNall, Scott. 1983. 'Pornography: The Structure of Domination and the Mode of Reproduction.' In Scott McNall (ed), Current Perspectives in Social Theory, Vol. 4, Greenwich: JAI Press Inc., pp. 181-203. 
Mitchell, Gregory. 2016. 'Evangelical Ecstasy Meets Feminist Fury: Sex Trafficking, Moral Panics, and Homonationalism during Global Sporting Events.' GLQ: A Journal of Lesbian and Gay Studies 23 (3): 325-357.

Morton, Mark. 2005. Dirty Words: The Story of Sex Talk. London: Atlantic Books.

Murray, Laura. 2014. 'Victim Management and the Politics of Protection: Between 'Fazer Direito' and 'Direitinho." Revista Artemis 18 (1): 28-41.

2018. 'Ossos de Ofício: Uma reflexão sobre o papel de papéis na gestão pública da prostituição.' Presentation at BRASA XIV Congress, Rio de Janeiro, Brazil, 26 July 2018.

Observatório da Prostituição. 2014. Prostitution During the World Cup, 2014. Rio de Janeiro: Observatório da Prostituição, LeMetro, UFRJ. At http://lemetro.ifcs.ufrj.br/world_cup_\%20report.pdf [Accessed on 9 January 2017].

2016. 'Attack on Trans and Prostitutes.' Sexual Policy Watch, 2 August. At http://sxpolitics. org/trans-and-prostitute-activists-under-attack-in-rio-de-janeiro/15272 [Accessed on 9 September 2017].

O’Neil, Maggie. 2012. 'The Source.' The Honest Courtesan. At https://maggiemcneill.wordpress. com/2012/11/27/the-source/ [Accessed on 9 September 2017].

2014. 'Lies, Damned Lies and Sex Work Statistics.' Washington Post, 27 March. At https://www. washingtonpost.com/news/the-watch/wp/2014/03/27/lies-damned-lies-and-sex-work-statistics/?utm _ term $=.1579 e e 9 b 0005$ [Accessed on 9 September 2017].

Orellano, Georgina. Forthcoming. Puta y Feminista. Crónicas de una Trabajadora Sexual. Buenos Aires: AMMAR.

Ortner, Sherry. 1974. 'Is female to male as nature is to culture?' In M Z Rosaldo and L Lamphere (eds), Women, Culture, and Society. Palo Alto: Stanford University Press, pp. 67-87.

1978. 'The Virgin and the State.' Feminist Studies 4 (3): 19-35.

Papadaki, Evangelia. 2010. 'Feminist Perspectives on Objectification.' In Edward N. Zalta (ed), The Stanford Encyclopedia of Philosophy. At http://plato.stanford.edu/archives/spr2010/entries/feminismobjectification/ [Accessed on 3 August 2018].

2007. 'Sexual Objectification: From Kant to Contemporary Feminism.' Contemporary Political Theory No. 6.

Piscitelli, Adriana. 2012. 'Exploração Sexual, Trabalho Sexual: Noções e Limites.' Corpos, Sexualidades, e Feminilidades Seminar, UERJ, Rio de Janeiro, September 2012.

Raccioppi, Katie. 2009. 'From 'Friend' to 'Whore.' Living Language: Politics, Philology, Theory. At www.http://livingwithlanguage.wordpress.com/2009/03/02/from-friend-to-whore [Accessed on $6 \mathrm{Au}$ gust 2017].

Red Light Rio. n.d. 'Red Light Rio.' At http://redlightr.io/ [Accessed on 6 August 2017].

Ringdal, Nils Johan. 1997. Love For Sale: A World History of Prostitution. New York: Grove Press.

Rubin, Gayle. 1975. 'The Traffic in Women: Notes on the "Political Economy" of Sex.' In R R Reiter (ed.), Toward an Anthropology of Women. New York: Monthly Review Press, pp. 157-210.

Schüssler-Fiorenza, Elisabeth. 1993. But She Said: Feminist Practices of Biblical Interpretation. Boston: Beacon Press. 
Silva, Denise Ferreira da. 2007. Towards a Global Concept of Race. Minneapolis: University of Minnesota Press.

Simmel, Georg. 1971. 'Prostitution.' In Donald Levine (ed), Simmel: On individuality and social forms. Chicago: Chicago University Press.

Simões, Soraya. 2016. 'Cidades imaginadas, cidades existentes: prostituição e a produção de uma narrativa crítica urbana.' 30a Reunião Brasileira de Antropologia: Políticas da Antropologia: ética, diversidade e conflitos, João Pessoa, Brazil.

Siqueira, Indianara. 2017. Um Século e Meio de Abolicionismo: Prostituição, Criminalização, e o Controle da Mulher. IFCS/UFRJ, Rio de Janeiro, Brazil, 9 August 2017.

Skackauskas, A and J M Nieto Oliva. 2010. 'Prostitutas, Feministas e Direitos Sexuais: Diálogos Possíveis ou Impossíveis?’ Fazendo Gênero Conference, Florianópolis, Brazil, 23-26 August 2010.

Strathern, Paul. 1996. Kant in 90 Minutes. Chicago: Ivan R. Dee.

Um Beijo para Gabriela. 2013. 'Porque Gabriela gosta da palavra puta/Why Gabriela prefers the word puta(whore)'. At https://www.youtube.com/watch? $v=C v K k G P i X v 0 o$ [Accessed on 6 August 2017]

Valenti, Jessica. 2015. 'Anita Sarkeesian interview: 'The word "troll” feels too childish. This is abuse." The Guardian, 29 August. At https://www.theguardian.com/technology/2015/aug/29/anita-sarkeesian-gamergate-interview-jessica-valenti [Accessed 9 September 2017].

Weber, Max. 2011 [1903-1917]. The Methodology of the Social Sciences. New York: Routledge.

\section{About the authors}

Thaddeus Blanchette holds a doctorate in social anthropology from the National $\mathrm{Mu}-$ seum of Brazil. He is currently an associate professor of anthropology at the Federal University of Rio de Janeiro (UFRJ - Macaé) and an associated researcher with Prostitution Policy Watch, a research and extension program of UFRJ. He has written and co-written close to 40 peer-reviewed articles on sex work, human trafficking, sex tourism and migrations. He is also the author of Cidadãos e Selvagens: Antropologia e Administração Indígena nos Estados, Unidos, 1870-1890. He lives in Rio de Janeiro with his partner Ana Paula da Silva and is a naturalized Brazilian citizen.

Ana Paula da Silva holds a doctorate in cultural anthropology from the Federal University of Rio de Janeiro. She is currently an adjunct professor of anthropology at the Federal Fluminense University (UFF - Santo Antônio de Pádua) and an associated researcher with Prostitution Policy Watch, a research and extension program of UFRJ. She is also currently president of the Davida Prostitutes' Rights collective. She has written and cowritten close to 30 peer-reviewed articles on sex work, human trafficking, sex tourism, race and gender, as well as the book Pele e o Complexo de Vira Latas. Ana was born and raised in the city of Rio de Janeiro, which is currently her home. 


\section{Putas Com Classe: Interseções entre Classe, Gênero, e Trabalho Sexual nas ideologias do Movimento Putafeminista no Brasil}

Resumo: O movimento de trabalhadoras do sexo do Brasil tem desafiado as narrativas hegemônicas sobre a venda de sexo por um tempo. Nos anos recentes, um sentimento anti-prostituição tem crescido no Brasil, ameaçando os direitos das trabalhadoras do sexo. Simultaneamente, a morte da ativista Gabriela Leite tem levado a uma renovação da liderança e reformulação de abordagens teóricas no movimento. Neste contexto, putafeminismo está se estabelecendo como uma abordagem interseccional para raça, classe e gênero enraizados em contextos historicos locais. $\mathrm{O}$ presente artigo, baseado em 12 anos de etnografia sobre os movimentos das trabalhadoras sexuais, apresenta entendimentos putafeminista de sexo, gênero, raça/cor e trabalho. Inspirado pela recuperação de Leite de 'puta' como um auto indicador para as trabalhadoras sexuais, e embasado na antropologia e historiografia feminista, putafeministas procuram resituar o termo como uma categoria mais ampla e profunda. Putafeministas recuperam 'puta' como um termo aplicado a mulheres trabalhando fora da família, desprotegidas da violência sexual. Olhando para a história brasileira, elas situam a venda de sexo como uma inevitabilidade prática para uma população trabalhadora feminina racialmente identificada cujos horizontes de possibilidade estavam baseados em trabalho barato, casamento e prostituição. Finalmente, putafeministas usam 'puta' como uma ponte para experiências da classe trabalhadora mais ampla, questionando os entendimentos de 'escravidão sexual' da pornofobia em um contexto histórico no qual mulheres são usualmente bens reais.

Palavras-chave: Putafeminismo; Prostituição; Interseccionalidade; Brasil; Putas.

Received on 30 January 2018, and approved for publication on 28 August 2018.

\section{(cc) BY-NC} https://creativecommons.org/licenses/by-nc/4.0/ 